\title{
ADIPOGENESIS TUMBUH KEMBANG ADIPOSIT
}

\author{
William S. Wangko \\ Sunny Wangko
}

\begin{abstract}
Bagian Anatomi-Histologi Fakultas Kedokteran Universitas Sam Ratulangi Manado
Email:wangkowilliam@yahoo.com
\end{abstract}

\begin{abstract}
Adipogenesis is defined as the growth and development of adipose tissue, which includes proliferation of adipose tissue cells and differentiation of these cells to become mature adipocytes. It is assumed that adipocytes are derived from multipotent messenchymal cells, fibroblasts, and resident adipocyte precursors in adipose tissues. Besides having genetic, nutritional, hormonal, and environmental factors, the progress of adipogenesis is influenced by angiogenesis and a variety of modulators (stimulators and inhibitors). Imbalance of all of these will trigger the formation of excessive adipose tissues, the result being obesity and its co-morbids. Adipose tissues can be used in accelerating the healing process of old wounds, revascularization of ischemic tissues, and in ongoing research as sources of cardiomyocytes in myocardial infarction.
\end{abstract}

Keywords: adipogenesis, adipocyte, proliferation, differentiation

\begin{abstract}
Abstrak: Adipogenesis merupakan proses tumbuh kembang jaringan adiposa yang meliputi proliferasi sel jaringan adiposa dan diferensiasinya menjadi adiposit dewasa. Sel adiposit diduga dapat berasal dari sel mesenkim multipoten, fibroblas, dan sel prekursor adiposit di dalam jaringan adiposa yang bertahan sepanjang hidup. Selain faktor genetik, nutrisi, hormonal dan lingkungan, perlangsungan adipogenesis juga dipengaruhi oleh angiogenesis serta berbagai modulator, baik yang bersifat stimulasi maupun inhibisi. Ketidakseimbangan yang terjadi pada kerja faktor-faktor tersebut dapat memicu pembentukan jaringan adiposa yang berlebihan, yang berakibat terjadinya obesitas berserta komorbidnya. Pemanfaatan jaringan adiposa telah dilakukan pada beberapa hal, antara lain mempercepat penyembuhan luka lama dan revaskularisasi jaringan iskemik. Walaupun masih dalam taraf penelitian, selsel jaringan adiposa telah dipertimbangkan sebagai sumber kardiomiosit pada infark jantung.

Kata kunci: adipogenesis, adiposit, proliferasi, diferensiasi
\end{abstract}

Dalam era globalisasi dewasa ini obesitas telah berkembang menjadi salah satu masalah kesehatan yang mendunia. ${ }^{1-4}$ Di Amerika Serikat obesitas telah mewabah dan mencapai sekitar $65 \%$ dari orang dewasa. ${ }^{5}$ Di Inggris tahun 2002 dilaporkan 23\% lakilaki dan $25 \%$ perempuan diklasifikasikan sebagai obes berdasarkan body mass index (BMI) $\geq 30$ dengan kenaikan tiga kali lipat dalam 20 tahun terakhir. ${ }^{6}$ Demikian pula di semua negara berkembang hampir setengah populasi mengalami kelebihan berat badan dan obesitas. ${ }^{5}$ Prevalensi pada anak di negara berkembang berkisar $15 \%-25 \%$, dan angka ini diperkirakan akan terus meningkat secara bermakna di masa depan. 5

Obesitas merupakan penimbunan jaringan adiposa putih yang berlebihan. ${ }^{1,3,7,8}$ Hal ini diakibatkan oleh ketidakseimbangan antara penggunaan energi dan asupan makanan, sehingga terjadi peningkatan timbunan energi dalam bentuk lemak di dalam jaringan adiposa., ${ }^{3,4}$ Terjadinya obesitas dipe- 
ngaruhi oleh banyak faktor antara lain faktor genetik, lingkungan, gaya hidup, underlying illness, dan status sosioekonomi. $^{2,4}$ Masalah klinis dari kelebihan jaringan adiposa dan obesitas berhubungan erat dengan beberapa penyakit kronik, antara lain hiperlipidemia, hipertensi, intoleransi karbohidrat dan diabetes melitus tipe 2 (DMT2), gout, keganasan, penyakit jantung koroner, artritis degeneratif, dan infertilitas. ${ }^{2-6}$ Selain itu jaringan adiposa menghasilkan berbagai sitokin (adipokin) yang mengatur homeostasis energi dan metabolisme di seluruh tubuh. ${ }^{1,6,9-12}$ Pada hakekatnya hubungan antara obesitas, adipokin dan penyakit-penyakit kronik di atas masih banyak yang belum dipahami. Data epidemiologi menyokong peran massa lemak, khususnya distribusi lemak tubuh pada perkembangan faktor resiko. ${ }^{2,11}$ Disamping itu, penurunan massa lemak tubuh ternyata selain mengurangi resiko dari penyakit kronik, juga menurunkan morbiditas dan mortalitasnya. ${ }^{2,12}$

Adipogenesis adalah proses pembentukan dan perkembangan adiposit sebagai sel utama penyusun jaringan adiposa. Adiposit merupakan sel pasca mitotik, sehingga untuk terjadinya hiperplasia dibutuhkan adiposit baru yang dihasilkan dari diferensiasi sel prekursor. Walaupun demikian identitas sel prekursor yang pasti in vivo masih belum jelas diketahui, demikian pula halnya dengan mekanisme selular dan molekular yang mendasari terjadinya adipogenesis. $1,3,9,11,13$

Proses adipogenesis mencakup konversi dari sel stem mesenkim menjadi preadiposit, yang selanjutnya berdiferensiasi menjadi adiposit. ${ }^{8,14}$ Unsur utama dari adipogenesis yaitu proliferasi sel stem embrionik menjadi sel stem yang telah terarah, yang selanjutnya berdiferensiasi menjadi adiposit atau sel vaskular. ${ }^{2,15}$ Peningkatan jumlah adiposit yang berasal dari sel prekursor adiposit disebut proliferasi/hiperplasia. ${ }^{1,2}$ Preadiposit sebagai sel prekursor adiposit dipercaya tetap ada sepanjang hidup dan telah dipelajari secara khusus melalui studi-studi in vitro dengan menggunakan biakan utama preadiposit. $^{2}$
Diferensiasi sel pada adipogenesis yang meliputi peralihan/perubahan dari preadiposit mirip fibroblas yang belum berdiferensiasi menjadi adiposit dewasa dicirikan oleh adanya perubahan morfologi menjadi sel bulat dengan droplet lemak unilokular. ${ }^{2,15}$ Studi in vivo dan in vitro memperlihatkan bahwa proliferasi dan diferensiasi preadiposit, waktu dan kecepatan hiperplasia, serta hubungan timbal baliknya sangat rumit dan dipengaruhi oleh berbagai faktor yaitu antara lain umur, spesies, depot jaringan adiposa, dan faktor modulator, baik yang sebagai stimulator maupun inhibitor. Faktor-faktor yang menstimulasi antara lain hormon, faktor stimulator angiogenesis, leptin, TNF-a, IGF-1, IL-6, dan IL-8 sedangkan yang menginhibisi antara lain SPARC dan inhibitor angiogenesis. Diferensiasi juga ditunjang oleh berbagai faktor transkripsional seperti famili PPAR, C/EBP dan bHLH, yang meregulasi dan menghasilkan gen-gen terkait (adipose-associated genes) untuk meningkatkan kapasitas lipogenik selsel tersebut. Peranan faktor stimulator dan inhibitor ini sangat kompleks dengan titik tangkap kerja yang berbeda-beda., 2,5, 12,16

Kelebihan energi yang tersimpan sebagai droplet lemak dalam adiposit akan mengkibatkan terjadinya hipertrofi adiposit sampai mencapai massa stabil dimana tidak terjadi pembesaran ukuran sel lagi melainkan peningkatan jumlah sel (hiperplasia) baik selama pertumbuhan normal, perkembangan ke arah obesitas, maupun pada gangguan metabolik. ${ }^{2,4}$ Walaupun peran hipertrofi dan hiperplasia adiposit pada obesitas tidak diragukan lagi, namun mekanisme yang mendasari perubahan/pertambahan jumlah adiposit secara keseluruhan, serta modulasi baik stimulasi maupun inhibisi, masih sangat kurang dipahami. ${ }^{3,12}$

\section{JARINGAN ADIPOSA}

Jaringan adiposa ditemukan pada semua spesies mamalia dan sejumlah spesies nonmamalia, serta merupakan satu-satunya jaringan dalam tubuh yang dapat bertambah massanya setelah mencapai usia dewasa. ${ }^{2,17}$ Manusia merupakan salah satu jenis mahluk 
yang lahir dengan cadangan lemak, yang mulai diakumulasi sejak 30 minggu kehamilan. $^{8}$ Massa jaringan adiposa dapat bervariasi dari $2-3 \%$ dari berat badan seorang atlit terlatih, ${ }^{2} 15-20 \%$ berat badan pada laki-laki dan $20-25 \%$ pada perempuan dengan berat badan normal ${ }^{8,17} 22 \%$ berat badan pada laki-laki dan $32 \%$ berat badan pada perempuan yang obes serta $60-70 \%$ berat badan pada individu yang obes masif. ${ }^{2}$

Jaringan ini ditemukan tersebar pada berbagai bagian tubuh, terutama pada tiga area anatomi: subkutan (inguinal, dorsosubkutan yaitu aksila dan interskapula), dermal (lapisan lemak yang berkesinambungan), dan intraperitoneal (depot mesenterik, omental, perirenal, retroperitoneal, serta epididimal dan parametrial). Keseluruhan depot jaringan adiposa ini disebut sebagai organ adiposa. ${ }^{2,17}$ Selain sebagai tempat cadangan energi, organ adiposa sekarang ini juga dikenal sebagai organ endokrin dan berperan mempertahankan homeostasis metabolisme dan energi. ${ }^{2,4,17,18}$

Jaringan adiposa merupakan jaringan ikat khusus yang didominasi oleh adiposit. Selain itu juga terdapat sel-sel stromavaskular termasuk sel mirip fibroblas, preadiposit, dan makrofag, sel endotel pembuluh darah, limfonodus, dan saraf dimana kesemuanya turut berperan dalam perlangsungan adipogenesis. Sel-sel tersebut ditemukan terisolasi atau berkelompok, tertanam di dalam jaringan ikat longgar dan jaringan ikat yang tak teratur. $2,3,7,8,12,19$

Terdapat dua jenis jaringan adiposa dengan lokasi, struktur, warna dan ciri histopatologik yang berbeda. ${ }^{8,17}$ Jaringan adiposa putih (white adipose tissue) yang lebih banyak ditemukan, dan didominasi oleh adiposit yang telah berkembang penuh, dengan satu droplet sentral yang besar berisi lemak berwarna kuning putih. Jaringan adiposa coklat (brown adipose tissue) mengandung sel-sel dengan banyak droplet lemak yang tersebar di antara mitokondria dan memberikan warna lebih gelap. Kedua jenis jaringan adiposa ini kaya dengan pasokan darah. Untuk selanjutnya yang akan dibahas adalah jaringan adiposa putih. $^{8}$

\section{ADIPOGENESIS}

Jaringan adiposa dewasa memperlihatkan adiposit dengan ukuran yang bervariasi, yaitu $30-40 \mu \mathrm{m}$ sampai $150-160 \mu \mathrm{m}^{17}$ termasuk adiposit yang sangat kecil (diameter $<3,5 \mu \mathrm{m}$ ) tergantung pada depot jaringan adipose. Dengan bertambahnya ukuran adiposit (diameter atau volum) disertai berkembangnya obesitas, heterogenisitas populasi adiposit menghilang. Hal ini menunjukkan adanya ukuran maksimal untuk adiposit, yang bervariasi antar spesies dan antar depot. $^{2,7,11}$

Pada manusia cadangan lemak mulai diakumulasi sejak 30 minggu kehamilan, dan telah berkembang baik pada saat lahir, baik lemak viseral maupun subkutan. ${ }^{8}$ Setelah lahir, perkembangan adiposit baru umumnya terjadi sekitar pembuluh darah kecil (Gambar 1) dimana ditemukan juga banyak sel mesenkim yang belum berdiferensiasi. ${ }^{2,8,13}$ Pasokan darah ke jaringan adiposa bermanfaat untuk mengangkut substrat metabolik dan mengeluarkan produk metabolik selular. Setiap adiposit cenderung berdekatan dengan kapiler darah. Walaupun aliran darah tampaknya sedikit bila dibandingkan dengan ke organ lainnya tetapi ternyata pada individu yang kurus organ adiposanya menerima 0,2-0,6L darah/menit, yaitu 3-7\% dari curah jantung. Pada obesitas, pasokan darah ke jaringan adiposa dapat mencapai $15-30 \%$ dari curah jantung; hal ini dapat memicu terjadinya hipertensi, kardiomegali, dan gagal jantung. ${ }^{2}$

Neovaskularisasi dan adipogenesis merupakan dua proses yang bergandengan selama prenatal sehingga diduga adiposit dan sel endotel penyerta mempunyai progenitor yang sama. ${ }^{5}$ Perkembangan sel lemak diawali oleh munculnya sejumlah kelompok sel lemak (disebut sebagai organ primitif) yang meningkat jumlah dan ukurannya selama perkembangan fetus. Perkembangan arteriol mendahului diferensiasi adiposit pada depot-depot lemak fetus, dengan kekhususan untuk masing-masing depot. Terdapat jalur autokrin dan parakrin sel endotel dan preadiposit. 


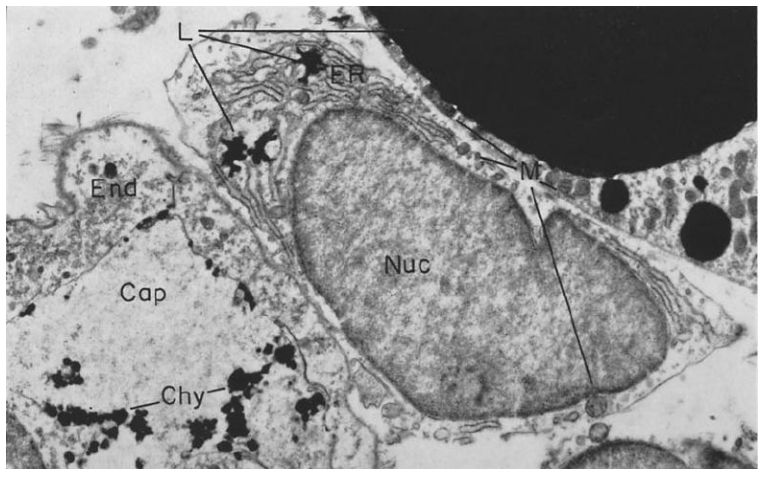

Gambar 1. Potongan jaringan adiposa yang sedang berkembang memperlihatkan kapiler (Cap) dengan kilomikron (Chy) di dalam lumen, sel stem berbentuk kumparan dengan banyak retikulum endoplasma dan mitokondria yang berbentuk sferis, serta sebagian sel signet-ring dengan inklusi lemak yang banyak dan bingkai sitoplasma yang mengandung mitokondria. Mitokondria berbentuk sferis dan filamen tampak pada sel dewasa. Perhatikan kedekatan hubungan kapiler dan sel adiposa. X 17.000. Sumber: Napolitano, 1963.

Kedua sel ini mengekspresikan $\alpha_{v} \beta_{3}$ integrin serta mengekpresi dan menyekresi PAI-1. yang mengatur migrasi preadiposit dan sel endotel in vitro. Produksi dan sekresi PAI-1 oleh preadiposit menjamin koordinasi adipogenesis dan angiogenesis. ${ }^{16}$ Adiposit yang teraktivasi menghasikan berbagai jenis faktor angiogenik, baik secara tunggal maupun bersama-sama menstimulasi neovaskularisasi selama perluasan jaringan adiposa. ${ }^{5}$

\section{Asal adiposit jaringan adiposa}

Sampai saat ini sel asal yang pasti dari adiposit masih diperdebatkan. Salah satu pendapat yaitu sel adiposa berasal dari sel fibroblas jaringan ikat. Selain itu terdapat pendapat yang mengatakan bahwa sel-sel tersebut berasal dari sel mesenkim, apakah sel mesenkim multipoten ${ }^{13}$ atau sel mesenkim sistem retikuloendotelial, oleh karena ternyata jaringan adiposa primordial memiliki struktur yang mirip dengan organ retikuloendotelial. ${ }^{2,20}$ Berbagai studi lanjut mengemukakan bahwa adiposit dapat berasal baik dari fibroblas maupun sel mesenkim yang multipoten (Gambar 2).

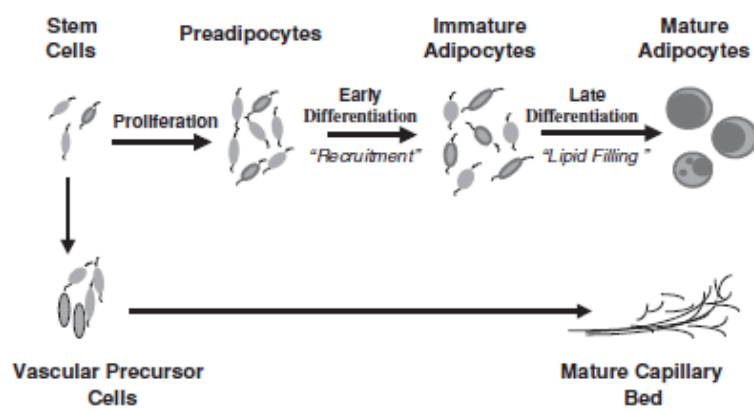

Gambar 2. Gambar skematik dasar dari perluasan jaringan adiposa. Proses utama yang terlibat disini adalah proliferasi populasi sel stem dan diferensiasi sel-sel ini menjadi sel adiposa atau vaskular. Sumber: Hausman et al, 2001.

Kemudian tergantung pada lingkungan, genetik, nutrisi, hormonal, serta jenis adipokin yang akan menstimulasi atau menginhibisi menjadi sel adiposa. ${ }^{8,20}$

Keadaan obesitas disertai oleh peningkatan jumlah adiposit. Spalding et al, 2008, dengan menggunakan marker C14 memperlihatkan bahwa adiposit secara berlanjut mengalami turn over pada manusia dewasa. Dengan diterimanya adiposit sebagai sel pasca mitotik, maka sangat diduga bahwa terdapat populasi sel prekursor adiposit di dalam jaringan adiposa yang bertahan sepanjang hidup. Penelitian mengenai regulasi massa jaringan lemak menemui kesulitan oleh karena sel prekursor adiposit yang fisiologik belum diketahui pasti, sehingga pemahaman proses tumbuh kembang jaringan adiposa dan mekanisme pengontrol regulasi jumlah adiposit in vivo menjadi sangat terbatas. ${ }^{3}$

\section{Proliferasi dan diferensiasi adiposit}

Tumbuh kembangnya jaringan adiposa meliputi hipertrofi selular (pertambahan ukuran sel) dan hiperplasia (pertambahan jumlah sel). Hipertrofi dihasilkan oleh akumulasi trigliserida yang berlebihan dalam adiposit yang telah ada oleh karena asupan energi melebihi penggunaannya, sedangkan hiperplasia, yang merupakan adipogenesis sesungguhnya, dihasilkan oleh pembentuk- 
an adiposit baru dari sel prekursor dalam jaringan adiposa, yang meliputi proliferasi dan diferensiasi preadiposit. Baik hipertrofi maupun hiperplasia terjadi oleh adanya keseimbangan energi yang positif selama pertumbuhan normal dan perkembangan obesitas, dimana hipertrofi sering mendahului hiperplasia secara siklik. ${ }^{2,4,21}$

Proses utama pada adipogenesis adalah proliferasi sel stem dan diferensiasi sel-sel ini menjadi adiposit atau sel vaskular. ${ }^{2,3}$

Proliferasi adalah peningkatan jumlah sel adiposa (disebut juga hiperplasia yang berasal dari sel prekursor adiposit. Preadiposit dipercaya tetap ada sepanjang kehidupan. Adiposit dewasa yang berisi lemak merupakan sel diferensiasi terminal yang umumnya tidak dapat membelah lagi. Walaupun penelitian cell line mengasumsikan bahwa proliferasi preadiposit terjadi sebelum diferensiasi, studi yang menggunakan preadiposit manusia menunjukkan bahwa sebagian sel-sel yang berdiferensiasi tetap mampu untuk bereplikasi. ${ }^{2,3}$

Diferensiasi adalah transisi dari preadiposit yang mirip fibroblas belum berdiferensiasi (undifferentiated fibroblast-like preadipocyte) menjadi sel adiposa dewasa yang bulat berisi lemak, ditandai oleh perubahan morfologik fibroblastik menjadi adiposit dewasa unilokuler. Terjadinya diferensiasi juga ditandai oleh ekspresi faktor-faktor transkripsi yang mengatur terjadinya ekspresi gen penyerta adiposa dan peningkatan kapasitas lipogenik dari sel. ${ }^{2}$

\section{Perubahan morfologik yang terjadi selama proliferasi dan diferensiasi sel jaringan adiposa.}

Napolitano $1963^{20}$ melakukan penelitian mikroskop elektron pada jaringan adiposa daerah inguinal dan epididimis pada tikus yang baru lahir sampai berusia sembilan hari. Jaringan adiposa mengandung sel-sel dengan berbagai variasi morfologik tergantung pada lokasi depot dan usia hewan coba. Terdapat sel-sel yang tersebar jarang dengan struktur fibroblas berbentuk kumparan, mengandung sedikit lemak, sampai ke sel dewasa berbentuk cincin stempel (signet ring cell). Akumulasi lemak merupakan kriteria yang jelas untuk membedakan stadium maturasi adiposit.

Diawali oleh adanya sel stem mirip fibroblas dengan empat sampai lima juluran protoplasma searah dengan sumbu panjang sel. Juluran tersebut panjang halus dan umumnya tidak mengandung inklusi. Sitoplasma perinuklear kaya dengan organela dan terdapat banyak retikulum endoplasma. Mitokondria kecil, bulat dengan struktur internal yang sederhana. Nukleus bulat sampai ovoid dan mempunyai satu-dua nukleoli dengan distribusi matriks intranuklear yang homogen. Tidak terdapat perubahan yang bermakna dari morfologi internal nukleus selama proses diferensiasi. Jaringan interstisial mengandung sejumlah besar serat kolagen terutama dekat sel disertai meningkatnya vaskularisasi. ${ }^{20}$

Dengan bertambahnya akumulasi lemak sel adiposa yang berdiferensiasi mengalami serangkaian tahap dimana terjadi modifikasi organela dan inklusi tertentu. Sel yang termuda berbentuk lonjong dengan nukleus di sentral. Terdapat banyak droplet lemak yang kecil pada ke dua sisi nukleus menuju kutub sel. Droplet lemak ini tidak dibungkus oleh membran. Membran plasma memperlihatkan pembentukan vesikel pinositosis. ${ }^{20}$

Sel bertambah besar menjadi bentuk ovoid. Jumlah sitoplasma bertambah, juga kandungan lemaknya. Umumnya droplet lemak telah bergabung membentuk satu droplet lemak. Pada tahap ini sejumlah glikogen tampak di sekitar droplet lemak. Pada stadium akhir diferensiasi sel berbentuk hampir bulat dengan nukleus yang terletak di perifer. Lemak terkumpul dalam satu droplet besar pada bagian tengah sel dan menggeser nukleus ke perifer. Terjadi penurunan yang drastis dari jumlah retikulum endoplasma. Mitokondria berbentuk filamen atau bulat, jumlah kristanya tidak banyak. Sitoplasma tetap mengandung sejumlah besar vesikel pinositosis pada membran plasma. ${ }^{17,20}$

Adiposit dewasa (signet ring cell) mempunyai droplet lemak sentral yang besar sehingga mengerdilkan organela lainnya. Nukleus berbentuk bulan sabit, terletak di 
perifer dan hanya dikelilingi oleh sedikit sitoplasma. Masih ditemukan banyak mitokondria dengan bentuk bervariasi tanpa struktur internal yang jelas. Sitoplasma mengandung komponen vesikel agranular dan sedikit retikulum endoplasma. Organela sel banyak ditemukan pada daerah perinuklear atau pada sitoplasma perifer. Sel dikelilingi oleh jala kolagen dan membran endotel dan sel adiposa sangat berdekatan. ${ }^{20}$

Dapat disimpulkan bahwa selama diferensiasi terjadi perubahan bentuk sel dari bentuk kumparan menjadi hampir bulat, akumulasi lemak mula-mula berbentuk inklusi kecil di salah satu kutub sel, kemudian membesar di bagian sentral sel sebagai hasil gabungan inklusi-inklusi sedang. Retikulum endoplasma yang pada awalnya terdapat berlimpah ternyata hampir menghilang seluruhnya pada tahap akhir dan tampak sebagai membran granula tersebar. Glikogen yang awalnya tampak disekitar droplet lemak pada stadium pertengahan, jarang tampak pada adiposit dewasa. Perubahan ultrastruktur yang nyata adalah berkembangnya membran basalis dan adanya pinositosis pada membran plasma. $^{20}$

\section{Modulasi adipogenesis}

Terdapat beberapa faktor yang diyakini memodulasi terjadinya adipogenesis, baik pada saat proliferasi maupun diferensiasi sel jaringan adiposa, serta adanya interaksi antara faktor-faktor tersebut. ${ }^{2,4}$

Telah dikenal beberapa faktor stimulasi seperti glukokortikoid yang bekerja meningkatkan jumlah preadiposit serta diferensiasi setiap lini preadiposit dan sel-sel stromavaskular bila terdapat insulin atau growth hormone. ${ }^{2,4}$ Penurunan aktivitas simpatis dapat memicu proliferasi sel adiposa. ${ }^{2}$ Juga terdapat beberapa faktor yang dilepaskan oleh jaringan adiposa yang bekerja secara autokrin/parakrin terhadap sel-sel sekitarnya. ${ }^{2,7}$ Faktor-faktor tersebut antara lain insulin-like growth factor-1 (IGF-1), IGF binding proteins (IGFBPs), transforming growth factor- $\beta$ (TGF $\beta$ ), macrophage colony-stimulating factor (MCSF), dan basic fibroblast growth factor (bFGF), ${ }^{2,4,5,9}$
Stimulator angiogenesis juga turut berperan untuk mempertahankan kelangsungan hidup adiposit. Termasuk disini adalah interleukin-8 (IL-8), hepatocyte growth factor (HGF), plasminogen activator inhibitor (PAI-1), matrix metalloproteinases (MMPs), leptin, dan vascular endothelial growth factor (VEGF). ${ }^{2,5}$ Faktor transkripsional seperti famili peroxisome proliferator-activated receptors (PPARs) dapat mendorong pertumbuhan dan dimulainya adipogenesis yang berawal dari sel fibroblas, serta berperan penting dalam pengaturan diferensiasi adiposit. Famili CCAAT/enhancer-binding protein (C/EBP) dan basic helix-loop-helix (bHLH) berperan dalam mengaktifkan program diferensiasi adiposit. $^{18}$

Berbagai faktor inhibisi seperti secreted protein acidic and rich in cysteine (SPARC), Wnt $/ \beta$-catenin, ${ }^{14}$ dan inhibitor angiogenesis antara lain angiopoietin-1 (Ang-1) dan transforming growth factor- $\beta$ (TGF- $\beta$ ) turut berperan dalam penghambatan proliferasi dan diferensiasi sel-sel jaringan adiposa. ${ }^{2,5}$

\section{BAHASAN}

Dewasa ini obesitas telah menjadi masalah kesehatan global di negara maju dan di negara berkembang. ${ }^{1-4}$ Obesitas telah melanda semua usia baik individu dewasa maupun anak-anak, dengan prevalensi yang cenderung meningkat secara bermakna dari tahun ke tahun. ${ }^{5,7}$ Hal yang menyangkut obesitas dan komorbidnya merupakan masalah yang serius baik dalam bidang kesehatan maupun sosio-ekonomi. ${ }^{5-7}$

Terdapat berbagai hal yang menyebabkan pencegahan dan pengobatan obesitas masih sulit untuk dilakukan. Data penelitian menunjukkan bahwa dari mereka yang telah berhasil menurunkan berat badan, ternyata kurang dari $10 \%$ yang dapat tetap mempertahankan berat badannya. ${ }^{2}$ Salah satu kesulitan yang dihadapi yaitu pemahaman mengenai mekanisme yang pasti mengenai terjadinya kelebihan berat badan maupun obesitas masih sangat terbatas, terlebih lagi aspek biomolekularnya. Juga gaya hidup 
yang berubah menjadi Western style, faktor lingkungan, status sosioekonomi, dan underlying illness turut berperan dalam terjadinya hal tersebut.,

Pada obesitas terjadi pertambahan massa jaringan adiposa, baik melalui proses hipertrofi maupun hiperplasia adiposit. ${ }^{2,4}$ Lester $^{21}$ mengemukakan bahwa terdapat dua jenis obesitas, yaitu yang hiperplasia/hiperselular dan hipertrofi. Pada jenis hiperplasia ditemukan peningkatan jumlah sel-sel jaringan adiposa berukuran normal atau sedang, terutama pada usia dini tahun-tahun pertama kehidupan dan sekitar usia 9-13 tahun, sedangkan jenis yang hipertrofi dengan sel-sel berukuran besar terjadi belakangan. Hal ini mungkin berkaitan dengan peran kontrol hormonal pada usia-usia tersebut.

Dalam hal modulasi adipogenesis, faktor stimulasi dan inhibisi serta angiogenesis, kesemuanya harus berkerja bersama-sama secara berimbang untuk mempertahankan tumbuh kembangnya jaringan adiposa yang normal. Berpatokan pada hipotesis ukuran kritis adiposit (critical fat cells hypothesis) ${ }^{2,7,14}$ bertambahnya jaringan adiposa selama perkembangan obesitas awal ditandai oleh hipertrofi adiposit dimana ukuran sel dapat mencapai 140-190 $\mu$ m. Sel-sel ini mempunyai kapasitas ekspansi yang terbatas sehubungan dengan batas difusi oksigen yaitu pada ukuran maksimal $100 \mu \mathrm{m}$. Peningkatan ukuran sel bila mencapai ukuran kritis akan menyebabkan terjadinya hipoksia jaringan adiposa yang selanjutnya akan memicu terjadinya proliferasi preadiposit baru. ${ }^{2,7,11}$ Adanya SPARC yang berperan dalam pematangan serat kolagen dan pembentukan fibrosis dapat membatasi pertumbuhan berlebihan dari jaringan adiposa. $^{14}$

Kapasitas ekspansi sel maksimal tergantung pada spesies, jenis kelamin, dan jenis depot jaringan adiposa. dikutip dari 2 Keadaan hipoksia ini akan menyebabkan terjadinya abnormalitas fungsi sel, terutama retikulum endoplasma dan mitokondria. Sejumlah protein membran dan sekretorik dibentuk di dalam retikulum endoplasma. Akumulasi protein-protein tersebut akan mengakibatkan keadaan stres pada organela ini. Sebagai konsekuensi selular dan sistemik yaitu terjadinya resistensi insulin pada adiposit, peningkatan produksi adipokin, asam lemak bebas, dan berbagai mediator inflamasi. ${ }^{4,11}$

Selain dipicu oleh keadaan hipoksia, pertambahan jumlah sel pada usia dewasa diduga juga disebabkan oleh mitosis adiposit dewasa. ${ }^{7}$ Hal ini tidak sejalan dengan pendapat yang telah umum diterima yang menyatakan adiposit sebagai sel pasca mitotik yang tidak dapat membelah lagi. ${ }^{3}$ Spalding et al 2008, ${ }^{\text {dikutip dari } 3}$ dengan menggunakan marker C14 menunjukkan bahwa adiposit secara berlanjut mengalami turn over pada manusia dewasa. Bila adiposit adalah sel pasca mitotik, maka sangat diduga bahwa populasi sel prekursor adiposit tetap ada di dalam jaringan adiposa. Penelitian untuk regulasi massa jaringan adiposa menemui kesulitan oleh karena sel prekursor adiposit yang fisiologik belum ditemukan, sehingga pemahaman proses tumbuh kembang jaringan adiposa dan mekanisme pengontrol regulasi jumlah adiposit in vivo menjadi sangat terbatas. ${ }^{3,13}$ Terjadinya kerancuan di atas antara lain disebabkan oleh karena kurangnya pemahaman mengenai asal yang pasti dari adiposit. Selain itu penelitian mengenai tahap proliferasi sel jaringan adiposa kurang diminati; umumnya perhatian dan studi yang dilakukan membahas mengenai diferensiasi preadiposit. ${ }^{2}$

Terjadinya adipogenesis harus ditopang oleh angiogenesis yang memadai. Terdapatnya stimulator dan inhibitor angiogenesis sangat berperan dalam mengatur angiogenesis yang cukup untuk pemeliharaan jaringan adiposa. ${ }^{16}$ Adanya stimulator angiogenesis ini memungkinkan digunakannya jaringan adiposa untuk merangsang penyembuhan luka lama dan revaskularisasi jaringan iskemik. Selain itu para peneliti mempertimbangkan bahwa bahan antiangiogenesis mungkin dapat berperan sebagai pengobatan baru untuk pencegahan dan pengobatan obesitas pada manusia dan komorbidnya. ${ }^{5}$

Faktor transkripsi PPARs terutama PPAR- $\gamma$ bila diaktifkan akan menstimulasi terjadinya diferensiasi preadiposit menjadi 
adiposit. Dengan demikian dapat menghambat terjadinya mitosis sel adiposa muda, dan secara tak langsung menghambat terjadinya obesitas jenis hiperplasia. Thiazolidinediones, golongan obat antidiabetes yang relatif baru, yang ternyata meningkatkan kepekaan insulin, dapat secara langsung mengikat dan mengaktifkan PPAR- $\gamma$ serta telah terbukti dapat menstimulasi diferensiasi adiposit, yang memberikan nilai tambah dalam pengobatan. ${ }^{15,18}$

Dengan kemajuan teknologi dan berpatokan pada perangai sel-sel jaringan adiposa, maka berbagai penelitian telah dilakukan untuk mengaplikasikan hal-hal tersebut dalam pengobatan. Prosedur bedah rekonstruksi dan bedah plastik untuk memperbaiki kehilangan jaringan adiposa yang diakibatkan oleh antara lain trauma, reseksi tumor, atau defek kongenital dengan menggunakan jaringan adiposa autologus masih sangat terbatas. Berkaitan dengan stem cell and adipose tissue engineering, telah dipikirkan pengunaan transplantasi preadiposit dan adiposit sebagai sumber sel jaringan adiposa. $^{22}$ Selain itu telah dipertimbangkan pemanfaatan adiposit sebagai sumber miosit jantung. Pengunaan sel punca yang pluripoten kurang diminati oleh karena efek teratogeniknya. Walaupun penggunaan sel punca multipoten mungkin lebih cocok untuk intervensi autologus, tetapi kemampuan berdiferensiasinya menjadi miosit jantung masih diperdebatkan. Pada tahun 2004 sel-sel stroma jaringan adiposa dibuktikan dapat berdiferensiasi menjadi miosit jantung yang dapat berkontraksi. ${ }^{19}$ Matsumoto et al ${ }^{\text {dikutip dari } 19}$ memperlihatkan bahwa pada kultur adiposit dewasa manusia, ternyata sel-sel ini kehilangan droplet lemak dan marker adiposit dewasanya, serta memperlihatkan morfologi seperti fibroblas yang berproliferasi, disebut dedifferentiated fat (DFAT) cells. Temuan ini membuka peluang untuk penggunaan sel-sel DFAT dalam hal regenerasi miosit jantung autologus, dibandingkan dengan sel punca atau progenitornya. ${ }^{19,23}$ Untuk itu masih diperlukan penelitian lebih lanjut dengan menggunakan kultur jaringan adiposa manusia.
Pemahaman mengenai adipogenesis dan modulasinya yang masih sangat terbatas perlu didukung oleh penelitian lanjut yang mencakup proses adipogenesis secara keseluruhan. Hal ini akan memudahkan pencegahan dan pengobatan obesitas serta komorbidnya, juga dalam hal aplikasi sel-sel jaringan adiposa pada penyakit lainnya.

\section{SIMPULAN}

Adipogenesis adalah proses tumbuh kembang jaringan adiposa yang meliputi proliferasi sel jaringan adiposa dan diferensiasinya menjadi adiposit dewasa. Sel prekursor adiposit yang fisiologik belum diketahui pasti. Diduga adiposit berasal sel mesenkim multipoten, sel fibroblas, dan sel prekursor adiposit yang bertahan selama hidup dalam jaringan adiposa. Selain faktor genetik, lingkungan, nutrisi, dan hormonal, perlangsungan adipogenesis perlu ditunjang oleh angiogenesis serta faktor modulator baik yang bersifat stimulasi maupun inhibisi.

\section{DAFTAR PUSTAKA}

1. Prokesch A, Hackl H, Hakim-Weber R, Bornstein SR, Trajanoski Z. Novel insights into adipogenesis from omics data. Current Medicinal Chemistry 2009;16: 2952-64.

2. Hausman DB, DiGirolamo M, Bartness TJ, Hasuman GJ, Martin RJ. The biology of white adipocyte proliferation. Obes rev. 2001;2:239-54.

3. Rodeheffer MS, Birsoy K, Friedman JM. Identification of white adipocyte progenitor cells in vivo. Cell 2008;135:240-9.

4. Ferranti S, Mozaffarian D. The perfect storm: Obesity, adipocyte dysfunction, and metabolic consequences [online]. 2008 [cited 2010 May 16]. Available from: http://www.clinchem.org/cgi/content/full/54/6/945

5. Cao Y. Angiogenesis modulates adipogenesis and obesity [online]. 2007 [cited 2010 May 16]. Available from: http://www.jci. org/articles/view/32239/version/1

6. Trayhurn P, Wood IS. Signalling role of adipose tissue: adipokines and inflamma- 
tion in obesity. Biochem society transactions 2005;33:1078-81.

7. Marques BG, Hausman DB, Martin RJ. Association of fat cell size and paracrine growth factors in development of hyperplastic obesity. Am J Physiol Regul Integr Comp Physiol. 1998;275(6): 1898-1908.

8. Mescher A. Junqueira's Basic Histology text and atlas (Twelfth Edition). New York: McGraw Hill Education, 2010.

9. Sakaue H, Konishi M, Ogawa W, Asaki T, Mori T, Yamasaki $M$ et al. Requirement of fibroblast growth factor 10 in development of white adipose tissue. Genes \& development 2001:16:908-12.

10. Schupp M, Lefterova MI, Janke J, Leitner K, Cristancho AG, Mullican SE et al. Retinol saturase promotes adipogenesis and is downregulated in obesity. PNAS 2009:106(4);1105-10.

11. Hosogai N, Fukuhara A, Oshima K, Miyata Y, Tanaka S, Katsumori $S$ et al. Adipose tissue hypoxia in obesity and its impact on adipocytokine dysregulation. Diabetes 2007:56;901-2.

12. Clement K, Viguerie N, Poitou C, Carette C, Pelloux V, Curat CA et al. Weight loss regulates inflammation-related genes in white adipose tissue of obese subjects. FASEB J. 2004;18:1657-58.

13. Prestwich TC, MacDougald OA. Wnt $/ \beta$ catenin signaling in adipogenesis and metabolism. Curr Opin Cell Biol. 2007; 19(6): 612-7.
14. Nie J, Sage H. SPARC functions as an inhibitor of adipogenesis. J Cell Commun Signal 2009;3:247-54.

15. Lazar M. A fat cell grows up: Stages from early to mature cell offer clues for antiobesity drug development [online]. 2010 [cited 2010 July 16]. Available from: www.physorg.com/news 193331234.html

16. Hausman GJ, Richardson RL. Adipose tissue angiogenesis. J Anim Sci. 2004; 82:925-34.

17. Cinti S. The adipose organ [online]. [cited 2010 July 15]. Available from: http://www.sioobesita.org/documenti/baveno003.pdf

18. Gregoire FM, Smas CM, Sul HS. Understanding adipocyte differentiation. Physiol rev. 1998;78:783-801.

19. Barbuti A. The 'Hearty' fat: adipocytes as a source of functional cardiomyocytes. Cardiovasc res. 2010;85:1-2.

20. Napolitano L. The Differentiation of white adipose cells. J Cell Biol. 1963;18:66378.

21. Salans LB, Cushman SW, Weismann RE. Adipose cell size and number in nonobese and obese patients. J Clin Inves. 1973; 52;929-41.

22. Gomillion CT, Burg KJL. Stem cells and adipose tissue engineering. Biomaterials 2006;27:6052-63.

23. Jumabay M, Zhang R, Yao Y, Goldhaber JI, Bostrom KI. Spontaneously beating cardiomyocytes derived from white mature adipocytes. Cardiovasc res 2010;85: 17-27. 